Vol. 7 No. 2 Juli 2018

E-ISSN : 2502-3101 P-ISSN : 2302-528x

http://ojs.unud.ac.id/index.php/jmhu

\title{
Prinsip Non Diskriminasi Tenaga Kerja Asing Dalam Kerangka GATS: Dimensi Kepariwisataan
}

\author{
A.A. Istri Eka Krisna Yanti ${ }^{1}$ \\ 1Program Studi Magister Ilmu Hukum, Fakultas Hukum Univeristas Udayana, \\ E-mail: gunkistri.legal@yahoo.com
}

\begin{tabular}{l}
\hline Info Artikel \\
\hline Masuk: 28 Pebruari 2018 \\
Diterima: 25 Juli 2018 \\
Terbit: 31 Juli 2018 \\
Keywords: \\
Foreign Labor; GATS; Labor \\
law; Tourism; Trade in services
\end{tabular}

Kata kunci:

GATS; Kepariwisataan; Tenaga Kerja Asing; Hukum Ketenagakerjaan

\section{Corresponding Author:}

A.A. Istri Eka Krisna Yanti, Email:gunkistri.legal@yahoo.com

DOI :

10.24843/JMHU.2018.v07.i02. p5

\begin{abstract}
This study aims to identify and elaborate the NonDiscrimination Principles of the GATS related to the use of foreign workers in the provisions of tourism. The main nondiscriminatory principle used in this study is the principle of Most Favoured Nation (MFN) and National Treatment. Indonesia agreed to be bound on GATS by promulgating law Number 7 the year 1994 regarding the Ratification of Agreement on Establishing the World Trade Organisation, that ensures Indonesia to obedient non-discrimination principle on Indonesia's regulations. As a member of GATS, Indonesia must submit a schedule of commitments that explain the types of services that are ready to apply the principle of nondiscrimination. This research is a normative legal research by examining norms, principles, and related legal aspect of foreign labor in Indonesia. The authors found that there was a conflict of norms in the application of the GATS non-discrimination principle in Indonesian labor law in the trade of foreign labor services. Indonesia actually has its own sovereignty that cannot be imposed by any party and in the application of GATS nondiscrimination principle not by contradicting Pancasila and the 1945 Constitution of the Republic of Indonesia as the basis of the development of employment.
\end{abstract}

\begin{tabular}{l} 
Abstrak \\
\hline Tulisan ini bertujuan untuk mengidentifikasi dan
\end{tabular}
mengelaborasi Prinsip Non Diskriminasi GATs terkait penggunaan Tenaga Kerja Asing dalam ketentuan kepariwisataan. Prinsip non diskrimininasi yang utama digunakan dalam penelitian ini adalah prinsip Most Favoured Nation (MFN) dan National Treatment. Indonesia setuju untuk terikat pada GATS dengan meratifikasi Undang-Undang Nomor 7 tahun 1994 tentang Pengesahan Agreement Establishing the World Trade Organization yang mengikat Indonesia untuk mematuhi prinsip-prinsip non diskriminasi dalam pengaturan perdagangan jasa di Indonesia. Sebagai anggota GATS, Indonesia harus menyerahkan komitmen yang berisikan jenis perdagangan jasa yang siap menerapkan prinsip non diskriminasi. Penelitian ini merupakan penelitian hukum normatif dengan meneliti norma, asas, dan bahan-bahan hukum penunjang terkait tenaga kerja asing di Indonesia. Hasil 
studi menunjukkan bahwa ada konflik norma dalam penerapan prinsip non-diskriminasi GATS dalam hukum ketenagakerjaan Indonesia, khususnya dalam penggunaan tenaga kerja asing. Indonesia sebenarnya memiliki kedaulatan tersendiri yang tidak dapat dipaksakan oleh pihak manapun dan dalam penerapan prinsip nondiskriminasi GATS tidak boleh bertentangan dengan Pancasila dan Undang-Undang Dasar Negara Republik Indonesia Tahun 1945 sebagai dasar pengembangan ketenagakerjaan.

\section{Pendahuluan}

Pariwisata telah menjadi salah satu sektor utama dalam perkembangan ekonomi dunia sejak abad ke-20 sebagaimana yang disebutkan oleh The World Tourism Organization (selanjutnya disebut UNWTO) sebagai berikut Tourism has become a major sector of economic activity since the latter part twentieth century and all indication are that it will continue growing the years to come. ${ }^{1}$ Sejak abad ke-20, eksistensi pariwisata telah melahirkan sederet peluang sekaligus tantangan bagi Negara-Negara yang menggantungkan hidupnya dalam industri pariwisata. Pariwisata telah memberikan dampak positif bagi pertumbuhan ekonomi suatu negara. Hasil studi Supasti, Nurmawati dan Sarna mengemukakan bahwa sektor pariwisata memiliki potensi besar meningkatkan pendapatan pajak negara melalui membuka lapangan pekerjaan baru. ${ }^{2}$ Lebih lanjut, hasil studi Iwan Rois, Luluk Fadliyanti, dan Saripta Wijimulawiani menunjukkan bahwa tingkat kunjungan wisata berpengaruh positif terhadap pendapatan asli daerah secara signifikan ${ }^{3}$, termasuk Indonesia.

Indonesia merupakan negara kepulauan yang terdiri atas pulau-pulau yang tersebar di sekitar garis khatulistiwa dengan populasi penduduk yang memiliki keanekaragaman budayanya masing-masing. Keanekaragaman budaya Indonesia dan letak geografis memberikan nilai tambah bagi perekonomian Indonesia dalam bidang kepariwisataan. Keunikan dan keanekaragaman budaya Indonesia yang didukung dengan keindahan alamnya, telah menempatkan pariwisata sebagai obyek dari kebijakan nasional sejak Indonesia mulai menentukan kebijakan pembangunan. Kebijakan kepariwisataan ditempatkan sebagai sub-kebijakan tersendiri. ${ }^{4}$

Saat ini, kebijakan pemerintah menetapkan pariwisata sebagai leading sektor ${ }^{5}$ dengan target 20juta wisatawan mancanegara dengan penghasilan devisa 260 Triliun pada akhir tahun 2019. Arief Yahya menyebutkan bahwa pariwisata merupakan penyumbang PDB,

${ }^{1}$ UNWTO. (2004). Sustainable Tourism in Protected Areas Guide Lines for Planning and Management. UNWTO. Madrid. Spain. h. ix.

2 Dharmawan, N. K. S., Nurmawati, N. M., \& Sarna, K. (2011). The Right to Tourism Dalam Perspektif Hak Asasi Manusia Di Indonesia. Kertha Patrika. h. 3

${ }^{3}$ Rois, I., Fadliyanti, L., \& Wijimulawiani, B. S. (2018). Dampak Pengembangan Pariwisata Terhadap Pendapatan Asli Daerah (PAD) Di Kabupaten Lombok Tengah Nusa Tenggara Barat Tahun 2002-2016. Journal of Economics and Business. 3(2). h. 26.

${ }^{4}$ Putra, I. B. W. et.al. (2003). Hukum Bisnis Pariwisata. Refika Aditama. Bandung. h.2

${ }^{5}$ Info Kementrian. Capaian Sektor Pariwisata 3 Tahun Jokowi-JK Kerja bersama, tersedia di http://www.presidenri.go.id/berita-aktual/laporan-3-tahun-pemerintahan-jokowi-jk-sektorpariwisata.html (diakses pada 21 Februari 2018 pukul 4.53 AM) 
devisa dan lapangan kerja yang paling mudah dan murah. ${ }^{6}$ Melalui pembangunan pariwisata, mampu menggerakan perekonomian bangsa dengan menstimulasi pembangunan industri-industri pendukung pariwisata lainnya. Perkembangan kepariwisataan Indonesia yang telah menghasilkan penghargaan-penghargaan pada sektor pariwisata secara internasional.

Pada tahun 2016 Indonesia mendapatkan 46 penghargaan kepariwisataan di 22 negara $^{7}$ dan 17 penghargaan pada tahun 2017. Penghargaan tersebut sebagai bukti dari potensi pariwisata Indonesia yang sudah diakui banyak negara sebagai tempat berlibur yang aman dan nyaman untuk dikunjungi wisatawan. Sejalan dengan itu, pada tahun 2016 jumlah kunjungan wisatawan mancanegara ke Indonesia sebanyak $11,51 \%$ dan pada tahun 2017 sebanyak 14,04 juta kunjungan atau naik sebesar 21,88\% ${ }^{\text {. }}$

Peningkatan jumlah kunjungan tersebut menimbulkan daya tarik bagi investor untuk membuka sektor-sektor usaha dalam bidang kepariwisataan sekaligus membuka lapangan pekerjaan baru. Namun, dibalik pesatnya perkembangan pariwisata Indonesia pada kenyataannya jumlah pengangguran bertambah 10 ribu orang ${ }^{9}$. Permasalahan pengangguran di Indonesia tidak dapat dipisahkan dari keberadaan Tenaga Kerja Asing (selanjutnya disebut TKA) yang dalam era global sangat dimungkinkan memasuki sektor usaha di Indonesia termasuk pariwisata.

Dalam perkembangan kepariwisataan Indonesia sesungguhnya memang memerlukan keterlibatan TKA, salah satunya sebagai sarana transfer knowledge. Keikutsertaan Indonesia dalam World Trade Organization (selanjutnya disebut WTO) merupakan faktor penentu terbukanya kesempatan bagi TKA untuk bekerja pada sektor jasa di Indonesia. Pada tanggal 15 April 1994 bertempat di Marrakesh Maroko, Pemerintah Indonesia telah menandatangani persetujuan WTO dan telah di ratifikasi Indonesia melalui UndangUndang Nomor 7 Tahun 1994 tentang Pengesahan Agreement Establishing of The World Trade Organization. Konsekuensi yuridis bagi Indonesia pasca meratifikasi WTO, Indonesia wajib melakukan perubahan-perubahan hukum yang berkaitan dengan perekonomian global dan regional. ${ }^{10}$ Melalui ratifikasi WTO Indonesia wajib mengharmonisasikan kebijakan hukum dalam perdagangan internasional sesuai dengan ketentuan WTO beserta seluruh annexes atau lampirannya yang terdiri atas, TRIMs, TRIPs dan GATS.11

${ }^{6}$ Ibid.

7 Info Kementrian. Pariwisata Indonesia Semakin Berjaya, tersedia di http://www.presidenri.go.id/info-kementrian-lembaga/pariwisata-indonesia-semakinberjaya.html (diakses pada 18 Februari 2018 pukul 6.04AM.)

8 Badan Pusat Statistik. (2018). Laporan Bulanan Data Sosial Ekonomi Edisi 93 Februari 2018, Badan Pusat Statistik. h.118.

9 Badan Pusat Statistik. Tingkat Pengangguran Terbuka, tersedia di https://www.bps.go.id/pressrelease/2017/11/06/1377/agustus-2017--tingkat-pengangguranterbuka--tpt--sebesar-5-50-persen.html (diakses pada 18 Februari 2018 pukul 6.28AM.)

10 Simamora, A., Nasution, B., Suhaidi, S., \& Siregar, M. (2014). Liberalisasi Pendidikan dalam Kerangka GATS: Kajian Hukum terhadap Pendirian Perguruan Tinggi Asing di Indonesia. USU Law Journal. 2(1). h. 67-89.

${ }^{11}$ Dharmawan, N. K. S. (2014). Keberadaan dan Implikasi Prinsip MFN dan NT dalam Pengaturan Hak Kekayaan Intelektual di Indonesia. Jurnal Magister Hukum Udayana (Udayana Master Law Journal). 3(2). 
Perdagangan internasional yang berkaitan dengan jasa secara khusus diatur dalam Annex 1B WTO yang dikenal dengan sebutan General Agreement on Trade in Services (selanjutnya disebut GATS). Kesepakatan yang terdapat dalam WTO-GATS bertujuan untuk pembangunan kerangka kerja multilateral dengan prinsip non diskriminasi sebagai bagian dari pelaksanaan Hak Asasi Manusia (selanjutnya disebut HAM). Pada article 1 Universal Declaration of Human Right (selanjutnya disebut UDHR) disebutkan "All human beings are born free and equal indignity and rights."12 Termasuk hak dalam bekerja yang secara khusus diatur dalam article 23 UDHR yang menentukan bahwa "Everyone has the right to work, to free choice of employment... without discrimination......"13

Prinsip non diskriminasi yang terdapat pada Article 23 UDHR, sesungguhnya telah tertuang dalam instrumen hukum nasional yaitu, Undang-Undang Nomor 13 Tahun 2003 Tentang Ketenagakerjaan (selanjutnya disebut UU Ketenagakerjaan yang bertujuan menjunjung tinggi harkat dan martabat manusia demi mewujudkan keadilan sosial dan ekonomi. ${ }^{14}$ Namun prinsip non diskrimasi yang terdapat dalam GATS jauh lebih spesifik dan berskala global yang meliputi prinsip Most Favoured Nation (MFN), National Treatment. ${ }^{15}$ Prinsip MFN merupakan salah satu prinsip yang paling penting dalam menunjang liberalisasi perdagangan internasional sebagaimana yang dikutip oleh Dony Yusra Pebrianto pada Rashhed Khalied et.al yang berpendapat bahwa "The most important and fundamental principle of the WTO is non discriminatory treatment or, to be legally precise, most favored nation (MFN) treatment."16 Prinsip MFN diatur dalam article II GATS yang pada intinya mengatur setiap anggota GATS harus dengan tanpa syarat memberikan perlakukan yang tidak berbeda (no less favourable) kepada penyedia jasa dari dalam ataupun luar negeri dengan secepatnya. Sedangkan pengaturan prinsip National Treatment terdapat dalam pasal XVII GATS yang mensyaratkan negara peserta GATS memberikan perlakuan yang sama antara jasa antara warga negara sendiri ataupun warga negara asing.

Selain prinsip MFN dan National Treatment, terdapat prinsip lainnya yang berkaitan erat dengan penerapan non diskiriminasi dalam GATS yaitu prinsip Transparansi, Progressive Liberalization atau liberalisasi yang dilakukan secara bertahap. ${ }^{17}$ Meskipun menganut prinsip non diskriminasi, WTO memberikan pengecualian-pengecualian pelaksanaan kewajiban bagi negara berkembang dan belum berkembang ${ }^{18}$ terhadap kewajiban-

12 Dharmawan, N. K. S. (2012). Tourism and Environment: Toward Promoting Sustainable Development of Tourism: A Human Rights Perspective. Indonesia. L. Rev. 2. h. 23.

13 Ibid.

14 Dewi, S. L., \& Sonhaji, B. I. (2017). Penerapan Prinsip Non Diskriminasi Dan Kesetaraan Dalam Pengupahan Bagi Pekerja/Buruh Di Kabupaten Kendal. Diponegoro Law Journal, 6(1), h. 1-21.

15 Santosa, A. G. D. H., Ranawijaya, I. B. E., Ariana, I. G. P., Salain, N. M. S. P. D., \& Widiatedja, I. P. (2011). Prinsip Non Diskriminasi Perjanjian General Agreement on Trade in Services (GATS) Pada Pengaturan Penanaman Modal Asing Di Bidang Pariwisata Di Indonesia. Kertha Patrika, h. 72.

16 Pebrianto, D. Y. (2018). Implikasi Prinsip Most Favoured Nation terhadap Pengaturan Tarif Impor Di Indonesia. Wajah Hukum. 2(1). 29-41. h. 30.

17 Ibid.

${ }^{18}$ Putra, I. B.W., \& Dharmawan, N. K. S. (2017). Hukum Perdagangan Internasional. Refika Aditama. Bandung. h. 88. 
kewajiban yang ditentukan dalam GATS. Selain itu, WTO menempatkan kedaulatan negara sebagai prinsip utama sistem kelembagaan dan sistem hukumnya. ${ }^{19}$

Melalui prinsip non diskirimasi GATS diharapkan dapat meningkatkan dan memperluas kesempatan kerja negara-negara peserta GATS sehingga dapat memberikan dampak positif bagi pembangunan ekonomi negara peserta GATS. Di sisi lainnya, prinsip non diskriminasi dalam perdagangan jasa menjadi tantangan tersendiri bagi Indonesia. Dalam Pasal 4 Undang-Undang Nomor 9 Tahun 2010 Tentang Kepariwisataan (selanjutnya disebut UU Kepariwisataan) jelas dinyatakan bahwa pada penyelenggaraan kepariwisataan bertujuan untuk meningkatkan pertumbuhan ekonomi, meningkatkan kesejahteraan rakyat, menghapus kemiskinan dan mengatasi pengangguran dengan adanya prinsip non diskriminasi tenaga kerja tentu kiranya dapat mempengaruhi pertumbuhan ekonomi, kesejahteraan rakyat tersebut bahkan justru berkontribusi dalam peningkatan jumlah pengangguran di Indonesia.

Berdasarkan uraian latar belakang diatas, jelas dapat dilihat besarnya peluang TKA dalam mengisi kebutuhan tenaga kerja di Indonesia yang dapat memicu peningkatan jumlah pengangguran di Indonesia untuk itu penulis tertarik melakukan penelitian dengan judul "Prinsip Non Diskriminasi Tenaga Kerja Asing Dalam Kerangka GATS: Dimensi Kepariwisataan". Adapun fokus kajian yang ingin dibahas dalam penelitian ini, sebagai berikut; Pertama, Bagaimanakah komitmen Indonesia terhadap GATS pada ketenagakerjaan dalam dimensi kepariwisataan? Kedua, Bagaimanakah pengaturan prinsip non diskriminasi GATS pada kebijakan hukum ketenagakerjaan Indonesia dalam dimensi kepariwisataan?

Tujuan dari penelitian ini fokus untuk memahami komitmen Indonesia terhadap GATS dan pengaturan prinsip non diskriminasi GATS pada kebijakan hukum ketenagakerjaan Indonesia dalam dimensi kepariwisataan.

Albertha Hartiana pada tahun 2016 telah melakukan studi tentang GATS namun fokus kajiannya pada perdagangan jasa pada sektor pendidikan tinggi. ${ }^{20}$ Begitu pula, Putu Ngurah Bagus Robin Cahya Putra telah melakukan penelitian atas GATS dengan fokus kajian pada Pengaturan Terhadap Advokat Asing Yang Beracara Di Indonesia di Tinjau dari Undang- Undang Nomor 18 Tahun 2003 Tentang Advokat ${ }^{21}$. Lebih lanjut, Frankiano B. Radang menekankan fokus studinya pada kesiapan tenaga kerja pada persaingan tenaga kerja asing. ${ }^{22}$ Studi-studi tersebut fokus kajiannya pada nondiscrimination principle GATS namun dalam studi ini lebih menekankan pada penerapan prinsip non diskriminasi yang terdapat di dalam GATS pada kebijakan hukum ketenagakerjaan Indonesia khususnya pada sektor kepariwisataan.

19 Ibid. h. 45.

${ }^{20}$ Hartiana, A. (2016). Prinsip-Prinsip Gats (General Agreement on Trade in Services) Terhadap Perdagangan Jasa Pendidikan Tinggi. Jurnal Magister Hukum Udayana (Udayana Master Law Journal), 5(4), h. 757-765.

${ }^{21}$ Putra, P. N. B. R. C., \& Landra, P. T. C. (2017) Pengaturan Hukum Terhadap Advokat Asing Yang Beracara Di Indonesia Ditinjau Dari Undang-Undang No 18 Tahun 2003 Tentang Advokat. Jurnal Magister Hukum Udayana (Udayana Master Law Journal), 6(2), h. 136-152.

22 Randang, F. B. (2011). Kesiapan Tenaga Kerja Indonesia Dalam Menghadapi Persaingan Dengan Tenaga Kerja Asing. Servanda_Jurnal Ilmiah Hukum. 5(1). 66-73. 


\section{Metode Penelitian}

Metode penelitian yang digunakan dalam penulisan ini adalah penelitian hukum normatif. Penelitian hukum normatif merupakan penelitian hukum yang dilakukan dengan meneliti bahan pustaka yang artinya dalam penelitian ini dilakukan dengan cara meneliti norma, asas, falsafah ataupun doktrin dan prinsip hukum dalam bahan-bahan kepustakaan. Penelitian hukum ini juga dikonsepkan sebagai penelitian perundangudangan (law in books) atau kaidah norma yang dianggap pantas sebagai patokan berperilaku.23. Jenis pendekatan yang digunakan dalam penelitian hukum ini adalah the Statue Approach dan the Analytical and Conceptual Approach sesuai dengan karakteristik dan sifat dari penelitian hukum normatif. Sumber bahan hukum yang digunakan dalam penelitian normatif ini menggunakan tiga bahan hukum yaitu, bahan hukum primer, bahan hukum sekunder dan bahan non hukum yang relevan digunakan untuk menganalisis prinsip non diskriminasi GATS dalam hukum kepariwisataan di Indonesia khususnya pada sektor kepariwisataan.

\section{Hasil Dan Pembahasan}

\subsection{Komitmen Indonesia Terhadap GATS Pada Ketenagakerjaan Dalam Dimensi Kepariwisataan}

Melalui pengesahan Agreements Establishing of The World Trade Organization, secara resmi telah mengikat Indonesia pada ketentuan WTO, termasuk lampirannya salah satunya adalah GATS. Persetujuan Indonesia atas GATS, membuka hambatan ruang pada tarif perdangangan jasa. ${ }^{24}$ Berdasarkan Pasal 3 Undang-Undang Nomor 24 Tahun 2000 Tentang Perjanjian Internasional (selanjutnya disebut UU Perjanjian Internasional), dinyatakan bahwa Indonesia mengikatkan diri pada perjanjian Internasional melalui cara-cara sebagai berikut;

1. Penandatanganan;

2. Pengesahan;

3. Pertukaran dokumen perjanjian / nota diplomatic

4. Cara-cara lain sebagaimana yang disepakati para pihak dalam perjanjian internasional. ${ }^{25}$

Perjanjian internasional bertujuan untuk membebankan negara peserta dengan kewajiban-kewajiban yang mengikat. Negara-Negara yang telah mengikatkan diri pada suatu perjanjian internasional, harus bersedia melaksanakan ketentuannya dan tidak menarik diri kewajiban-kewajiban yang telah mengikatnya tanpa adanya kesepakatan dari negara-negara anggota lainnya.

Dalam Pasal 1 pengesahan WTO, dengan tegas Indonesia menyatakan telah mengesahkan Agreement Establishing the World Trade Organization beserta lampirannya, yang mana salinan aslinya dalam bahasa Inggris beserta terjemahannya dalam bahasa Indonesia juga turut dilampirkan sebagai bagian yang tidak terpisahkan dari UU WTO. Selanjutnya dalam bagian penjelasan Pasal 1 UU WTO dinyatakan bahwa, apabila

${ }^{23}$ Subekti, R. P. (2018). Urgensi Ratifikasi Konvensi International Labor Organization: Perspektif Perlindungan Pekerja Anak Pada Sektor Rumah Tangga. Jurnal Magister Hukum Udayana (Udayana Master Law Journal). 7(1). 24-36.

${ }^{24}$ Made, P. I., \& Wayan, S. I. (2015). Model Hubungan Pariwisata, Kinerja Perekonomian Dan Kemiskinan Di Kabupaten Badung, Bali. Piramida. Denpasar. h. 96.

${ }^{25}$ Pasal 3 UU Perjanjian Internasional 
terjadi perbedaan penafsiran antara naskah terjemahan dalam bahasa Indonesia dan bahasa inggris, maka yang berlaku adalah salinan dalam bahasa Inggris.

Dokumen utama GATS merupakan kerangka kerja (framework agreement) yang mencakup aturan permainan yang berlaku secara umum bagi semua sektor-sektor di bidang jasa. ${ }^{26}$ Tujuan dari dibentuknya GATS adalah untuk menciptakan kondisi transparansi dan liberalisasi dalam kerangka multilateral dalam prinsip -prinsip dan aturan dalam perdagangan jasa. Dalam konsep GATS, ditentukan bahwa perdagangan jasa adalah penyediaan jasa yang mencakup;

1. Dari wilayah satu negara ke negara lainnya;

2. Dalam wilayah satu negara untuk konsumen jasa dari negara lainnya;

3. Oleh penyedia jasa dari suatu negara dengan membuat usaha pamasok jasa di wilayah negara lain;

4. Oleh penyedia jasa suatu negara dengan menghadirkan natural person di wilayah negara lainnya. ${ }^{27}$

Jasa dalam GATS meliputi semua sektor jasa, kecuali jasa yang dipasok untuk keperluan fungsi pemerintah. ${ }^{28}$ Perdagangan jasa mencakup seluruh aktivitas yang terorganisir secara kualitas, kuantitas dan dalam rentang waktu tertentu untuk membantu seseorang atau mendapatkan keinginannya berdasarkan proses transaksi, dan imbalan tertentu (services charge). ${ }^{29}$

Prinsip non-diskriminasi MFN dan National Treatment dalam perdagangan jasa mengakibatkan negara peserta GATS tidak dapat memberikan suatu perbedaan kepada tenaga kerja lokal sebagai proteksi kesejahteraan rakyatnya. Sebagai konsekuensi dari komitmen Indonesia pada GATS, Indonesia harus membuka pasarnya terhadap perdagangan barang dan jasa dari negara anggota WTO lainnya. ${ }^{30}$ Tindak lanjut prinsip non diskriminasi, maka penerapan konkret GATS, Indonesia berkewajiban untuk membuat komitmen yang disebut schedule of commitments (selanjutnya disebut SOC). SOC ini mencantumkan sektor-sektor yang terbuka serta jenis transaksi yang dapat dilakukan dalam perdagangan jasa. Adanya pengaturan mengenai SOC menimbulkan konsekuensi bahwa setiap negara peserta GATS harus mematuhi dan menjalankan komitmen yang telah disepakati.

Pemerintah Indonesia telah menyampaikan kesediaannya untuk meliberalisasi 5 sektor jasa yaitu; jasa keuangan, jasa telekomunikasi, jasa perhubungan laut, jasa industri yang di dalamnya termasuk jasa konstruksi dan pariwisata. ${ }^{31}$ Khusus komitmen dan liberalisasi jasa di sektor jasa pariwisata Indonesia telah menetapkan dan membuka tiga sub sector yaitu; Hotel, Travel Agent dan Tour Operator serta Tourist Resort tercakup di dalamnya Marinas, Golf Course dan fasilitas olahraga lainnya. Berdasarkan SOC yang diserahkan Indonesia kepada GATS pada 15 April 1994 yang berlaku hingga 2020, dapat diketahui rincian posisi tenaga kerja asing sebagai berikut:

26 Santosa, A. A. G. D. H., et. al. loc.cit., h. 73.

27 Putra, I. B. W. \& Darmawan, N. K. S. loc.cit. h. 88.

28 Ibid. h. 27.

${ }^{29}$ Putra, I. B. W. \& Darmawan, N. K. S. loc.cit., h. 2.

${ }^{30}$ Frankiano B. Randang, loc.cit, h. 66.

${ }^{31} \mathrm{Ibid}, \mathrm{h} .108$ 
1. Pada usaha perhotelan bahwa Indonesia tidak terikat atau tidak ada komitmen kecuali untuk posisi tertentu yaitu;

a. Top Management Level dalam bisnis perhotelan yaitu;

i) General manager

ii) Food and Beverage Manager

iii) Resident Manager

iv) Comptroller

v) Marketing Director 32

b. Tenaga Ahli Profesional perhotelan seperti;

i) Executive Chef

ii) Sous Chef

iii) Specialty Cook ${ }^{33}$

2. Dalam usaha Travel Agent dan Tour Operator hanya membolehkan maksimum 30 Travel Agent (TA) dan Tour Operator (TO) bagi pemasok jasa asing serta TA dan TO haruslah berkedudukan di Jakarta dan Bali. ${ }^{34}$

3. Dalam usaha Tourist Resort Marinas, Golf Course dan fasilitas olahraga lainnya tidak terikat atau tidak ada komitmen kecuali untuk Resort Manager.

\subsection{Pengaturan Prinsip Non Diskriminasi GATS Pada Kebijakan Hukum Ketenagakerjaan Indonesia Dalam Dimensi Kepariwisataan}

Indonesia telah memasuki liberalisasi perdagangan jasa yang berimplikasi pada kepentingan Indonesia. Indonesia merupakan negara yang menganut sistem ekonomi kerakyatan yang mengikut sertakan seluruh lapisan masyarakat dalam proses pembangunan. Merujuk pada teori penjenjangan norma Hans Kelsen yang berpendapat bahwa norma hukum itu berjenjang-jenjang dan berlapis-lapis dalam satu hirarki yang tidak boleh saling bertentangan antara satu dan lainnya. Prinsip non diskriminasi GATS merupakan suatu hukum internasional yang pada prinsipnya harus sesuai dengan norma dasar sesuai dengan hirarki perundangan-undangan di Indonesia.

Hirarki perundangan-undang Indonesia diatur dalam Pasal 7 Undang-Undang Nomor 12 Tahun 2011 Tentang Pembentukan Peraturan Perundang Undangan (selanjutnya disebut UU PPPU) yang menyatakan sebagai berikut;

1. Undang-Undang Dasar Negara Kesatuan Republik Indonesia Tahun 1945

2. Ketetapan Majelis Permusyawaratan Rakyat

3. Undang-Undang / Peraturan Pemerintah Pengganti Undang-Undang

4. Peraturan Pemerintah

5. Peraturan Presiden

6. Peraturan Daerah Provinsi

7. Peraturan Daerah Kabupaten/Kota ${ }^{35}$

32 GATS Indonesia Schedule of Specific Commitments, tersedia di https://docs.wto.org/dol2fe/Pages/FE_Search/FE_S_S009-

DP.aspx?language $=$ E\&CatalogueIdList $=10332,11366,37274,16557 \&$ CurrentCatalogueIdIndex $=3$ \&FullTextHash=\&HasEnglishRecord=True\&HasFrenchRecord=True\&HasSpanishRecord=True, di akses pada 5 Mei 2018 pukul 1.16AM.

33 Ibid.

34 Ibid.

35 Pasal 7 UU PPPU 
Terkait prinsip non diskriminasi dalam GATS yang merupakan ketentuan dari hukum internasional, tentunya harus disesuaikan dan diakomodir dengan baik sehingga tidak bertentangan dengan Pancasila dan UUD NKRI 1945 sebagai landasan pembangunan ketenagakerjaan Indonesia.

\subsubsection{Prinsip Non Diskriminasi Pada UU Ketenagakerjaan}

Pengaturan prinsip non diskriminasi telah diharmonisasikan oleh UU Ketenagakerjaan, dimana pada bagian menimbang huruf d UU Ketenagakerjaan dengan tegas dan jelas disebutkan bahwa perlindungan tenaga kerja bertujuan untuk menjamin hak dasar, kesamaan kesempatan serta perlakuan tanpa diskriminasi atas dasar apapun demi mewujudkan kesejahteraan pekerja dan keluarganya. Namun pada hahekatnya, pasal 2 UU Ketenagakerjaan juga memberikan batasan bahwa pembangunan ketenagakerjaan berlandaskan pada Pancasila dan UUD NKRI 1945 yang artinya sebagai negara yang berdaulat, berdasarkan hirarkinya UUD NKRI memiliki kekuasaan tertinggi, dengan demikian maka pengaturan atas kebijakan ketenagakerjaan Indonesia haruslah bersesuaian dengan UUD NKRI.

Penggunaan, TKA secara khusus dalam Bab VIII UU Ketenagakerjaan dimana dalam Pasal 42 ayat (1) setiap pemberi kerja yang memperkerjakan TKA wajib memiliki izin tertulis dari menteri atau pejabat yang dirujuk. Pasal 42 ayat (4) UU Ketenagakerjaan menentukan bahwa TKA yang dapat bekerja di Indonesia hanya dalam hubungan kerja untuk jabatan dan waktu tertentu, selanjutnya Pasal 42 ayat (6) menegaskan bahwa apabila masa kerja TKA tersebut habis tidak dapat diperpanjang dan digantikan oleh TKA lainnya. Selain itu, Indonesia tidak dapat memperkerjakan TKA untuk jabatan yang mengurus personalia sesuai dengan ketentuan Pasal 46 ayat (1) UU Ketenagakerjaan.

\subsubsection{Prinsip Non Diskriminasi Pada UU Kepariwisataan}

Pasal 4 UU Kepariwisataan menegaskan bahwa salah satu tujuan kepariwisataan adalah meningkatkan kesejahteraan rakyat dan diselenggarakan dengan prinsip memberdayakan masyarakat setempat. ${ }^{36}$ Rakyat dan masyarakat setempat yang dimaksudkan dalam UU Kepariwisataan tentunya merupakan warga negara Indonesia. UU Kepariwisataan juga memberikan pengaturan atas ketenagakerjaan secara khusus.

Dalam Pasal 53 UU Kepariwisataan ditetapkan bahwa tenaga kerja dalam bidang kepariwisataan memiliki standar kompetensi yang dilakukan melalui sertifikasi kompetensi oleh lembaga sertifikasi profesi yang telah mendapatkan lisensi sesuai dengan ketentuan undang-undang, termasuk juga pada TKA.

Pasal 56 UU Kepariwisataan menyatakan TKA yang dapat bekerja di pada industri pariwisata Indonesia hanyalah TKA Ahli yang telah mendapatkan rekomendasi dari organisasi pekerja professional kepariwisataan. Saat pemberian izin kerja kepada TKA, pemerintah mempertimbangkan pula keadaan dan perkembangan pasar kerja, serta apresiasi nasional untuk menduduki tempat-tempat yang penting dalam segala lapisan

36 Pasal 5 huruf e. UU Kepariwisataan 
masyarakat. ${ }^{37} \mathrm{Hal}$ ini penting dilakukan untuk menjamin kesempatan kerja bagi warga negara Indonesia, meskipun belum sepenuhnya sesuai dengan prinsip non diskriminasi.

\subsubsection{Prinsip Non Diskriminasi Pada Peraturan Menteri Ketenagakerjaan Republik Indonesia Nomor 35 Tahun 2015 Tentang Perubahan Atas Peraturan Menteri Ketenagakerjaan Nomor 16 Tahun 2015 Tentang Tata Cara Penggunaan Tenaga Kerja Asing}

Pada article II ayat 1 GATS, dengan jelas disebutkan bahwa setiap Negara peserta WTO harus dengan segera dan tanpa syarat memberikan perlakuan yang tidak berbeda terhadap jasa dan pemasok jasa dari Negara lain dengan Negara lainnya, termasuk perlakuan antara Tenaga Kerja Indonesia (selanjutnya disebut TKI) dan TKA. Terkait penggunaan TKA, pemasok jasa asing yang ingin melayani jasa di Indonesia harus hadir di Indonesia dalam bentuk Kantor Perwakilan Wilayah dan/atau usaha patungan (joint venture) dalam bentuk Perseroan Terbatas, Pemberi kerja orang perseorangan dilarang mempekerjakan TKA sebagaimana ketentuan dalam Pasal 42 ayat (2) UU Ketenagakerjaan. Batasan posisi TKA yang diberikan oleh pemerintah Indonesia yaitu, pada level direktur, manager dan penasehat ahli atau teknis.

Dalam hal pembatasan umum maupun sektoral Indonesia membatasi bahwa TKA yang diperkenankan bekerja di Indonesia harus memenuhi kualifikasi keahlian dan memiliki ijin kerja tetap diberlakukan tata cara keimigrasian pada saat memasuki wilayah Indonesia. Dalam memperkerjakan TKA, pemberi kerja juga harus menyiapkan tenaga kerja warga negara Indonesia sebagai pendamping TKA yang dipekerjakan. ${ }^{38}$ Pendampingan TKA oleh TKI merupakan salah satu upaya dalam rangka alih teknologi dan keahlian, karena penggunaan TKA tidak bisa selamanya bekerja di Indonesia. Setiap 6 (enam) bulan pemberi kerja wajib melaporkan penggunaan TKA termasuk pelaksanaan pendidikan dan pelatihan tenaga kerja pendamping.

Sebelumnya, pada tanggal 29 Juni 2015 ditetapkan Peraturan Menteri Ketenagakerjaan Republik Indonesia Nomor 16 Tahun 2015 Tentang Tata Cara Penggunaan Tenaga Kerja Asing (selanjutnya disebut Permen Tata Cara Penggunaan TKA), berdasarkan Pasal 3 ayat (1) Permen Tata Cara Penggunaan TKA menyatakan bahwa pemberi kerja yang memperkerjakan 1 (satu) orang TKA, sekurang-kurangnya harus dapat menyerap 10 (sepuluh) orang TKI. Akan tetapi, hal ini tidak berlaku sepenuhnya karena berdasarkan Pasal 3 ayat (2) Permen Tata Cara Penggunaan TKA terdapat pengecualian atas perbandingan ini jika TKA yang dipekerjakan untuk posisi tertentu, untuk pekerjaan yang sifatnya darurat dan mendesak, untuk pekerjaan yang sifatnya sementara dan / atau untuk usaha jasa impresariat.

Saat ini, berselang 5 bulan pasca ditetapkan dan diundangkannya Permen Tata Cara Penggunaan TKA, terdapat perubahan atas Permen tersebut. Berdasarkan Pasal 1 Peraturan Menteri Ketenagakerjaan Republik Indonesia Nomor 35 Tahun 2015 Tentang Perubahan Atas Peraturan Menteri Ketenagakerjaan Nomor 16 Tahun 2015 Tentang Tata Cara Penggunaan Tenaga Kerja Asing (selanjutnya disebut Perubahan Permen Tata Cara Penggunaan TKA), menentukan penghapusan Pasal 3 Permen Tata Cara

\footnotetext{
${ }^{37}$ Santosa, A. G. D. H., Ranawijaya, I. B. E., Ariana, I. G. P., Salain, N. M. S. P. D., \& Widiatedja, I. P., loc.cit. h. 78.

38 Pasal 43 (ayat 2) huruf d UU Ketenagakerjaan.
} 
Penggunaan TKA yang mengatur perbandingan rasio minum penggunaan TKA dan TKI. Penghapusan ketentuan Pasal 3 Permen Tata Cara Penggunaan TKA secara otomatis membebaskan kewajiban bagi perusahaan pemberi kerja TKA untuk menyerap TKI dalam jumlah tertentu.

Penghapusan Pasal 3 Permen TKA ini dikhawatirkan akan menghilangkan kesempatan kerja bagi TKI di negerinya sendiri dan meningkatkan jumlah pengangguran di Indonesia. Hal ini, pada sejatinya juga bertentangan dengan asas, fungsi dan tujuan dalam penyelenggaraan kepariwisataan. Putu Tuni Cakabawa Landra menyebutkan bahwa peran penting dari kepariwisataan adalah untuk memperluas dan memerantakkan lapangan kerja dalam rangka meningkatkan kesejahteraan dan kemakmuran rakyat. ${ }^{39}$ Sejalan dengan itu, Pasal 26 huruf g UU Kepariwisataan menentukan bahwa setiap pengusaha pariwisata berkewajiban mengutamakan penggunaan produk masyarakat setempat, produk dalam negeri dan memberikan kesempatan kepada tenaga kerja lokal.

Penghapusan perbandingan tenaga kerja ini merupakan pembuktian komitmen Indonesia atas GATS untuk tidak berlaku diskirimasi dan pelaksanaan atas pasal 5 huruf g UU Kepariwisataan untuk mematuhi kode etik kepariwisataan dan kode etik kesepakatan internasional. ${ }^{40}$

Perlakuan diskriminasi tenaga kerja dalam bentuk apapun pada hakekatnya bertentangan dengan prinsip non diskirimasi GATS, tetapi terdapat pengecualian untuk negara berkembang dan belum berkembang. Sesuai dengan prinsip Progressive Liberalization atau liberalisasi secara bertahap yang termuat dalam persetujuan. ${ }^{41}$

Pada kenyataannya dalam SOC, Indonesia telah memberikan batasan-batasan atas posisi tertentu yang dapat diisi oleh TKA. Mahmul Sinegar menyatakan bahwa adanya pembatasan khusus terhadap TKA dalam sektor jasa berdasarkan hukum positif Indonesia masih diperbolehkan. ${ }^{42}$ WTO mengatur mengenai perlakukan khusus dan berbeda yang disebut dengan Special and Differential Treatment untuk Negara berkembang guna memfasilitasi agar dapat dengan lebih cepat masuk kedalam sistem perdagangan dunia dan mendorong pembangunan ekonomi ${ }^{43}$, termasuk Indonesia sebagai negara berkembang yang berdaulat.

Sejalan dengan prinsip Special and Differential Treatment, WTO telah menempatkan kedaulatan negara anggotanya sebagai prinsip utama sistem kelembagaan dan sistem hukum pelaksanaan prinsip non diskriminasi GATS. Dengan demikian Indonesia memiliki haknya sendiri dalam menentukan sejauh mana prinsip non - diskirimasi

${ }^{39}$ Landra, P. T. C. (2018). Hukum Investasi dalam Industrialisasi Kepariwisataan Bali. Jurnal Magister Hukum Udayana (Udayana Master Law Journal). 7(1). h. 100-121

40 Adipatni, S. A. D. (2018). Perlindungan Hukum terhadap Wisatawan yang Mendapat Perlakuan Diskriminatif. Jurnal Magister Hukum Udayana (Udayana Master Law Journal). 7(1). h. 122-132.

${ }^{41}$ IGN Parikesit Widiatedja. (2011). Kebijakan LIberalisasi Pariwisata Konstruksi Konsep Ragam Masalah dan Alternatif Solusi.Udayana Press. Denpasar. h.103.

42 Ibid, hlm.79.

${ }^{43}$ Korah, R. S. (2016). Prinsip-prinsip Eksistensi General Agreement on Tariffs and Trade (GATT) Dan World Trade Organization (WTO) Dalam Era Pasar Bebas. Jurnal Hukum UNSRAT. 22(7). 
GATS dilakukan. Prinsip kedaulatan negara yang merupakan prinsip utama dalam WTO, Indonesia sebagai negara yang berdaulat berarti mempunyai kekuasaan yang tertinggi ${ }^{44}$ untuk itu Indonesia sebagai negara peserta GATS dapat menentukan sendiri sistem ekonomi yang merupakan hak mendasar bagi setiap negara yang tidak bisa dipaksakan oleh negara lain. ${ }^{45}$

\section{Kesimpulan}

Komitmen Indonesia dalam menerapkan prinsip non diskriminasi GATS dalam dimensi kepariwisataan dapat dikatakan berlebihan, karena pada hakekatnya kedaulatan negara merupakan prinsip utama dalam sistem kelembagaan WTO. Selain itu, WTO menerapkan prinsip Progressive Liberalization pada negara-negara berkembang termasuk Indonesia. Dengan demikian, sebagai negara yang terikat pada WTO Indonesia memilki hak untuk menentukan sejauh mana terikat pada prinsip non diskriminasi GATS dengan tetap memperhatikan tujuan dari penyelenggaraan kepariwisataan yaitu menyejahterakan rakyat salah satunya melalui penyediaan lapangan pekerjaan.

Ketentuan penyediaan jasa TKA yang berlaku saat ini, bahkan memberikan peluang bagi TKA yang bukan merupakan negara peserta GATS. Oleh sebab itu, maka pemerintah Indonesia perlu menerapkan kebijakan yang lebih mengutamakan kesejahteraan masyarakat sebagaimana yang terdapat dalam asas hukum ketenagakerjaan yang berlandaskan pada Pancasila dan UUD NKRI 1945 untuk mewujudkan tujuan dari penyelenggaraan kepariwisataan.

\section{Daftar Pustaka}

Buku

Badan Pusat Statistik. (2018). Laporan Bulanan Data Sosial Ekonomi Edisi 93 Februari 2018, Badan Pusat Statistik

Putra, I. B. W. (2003). Hukum Bisnis Pariwisata. Bandung: Refika Aditama.

Putra, I. B. W., \& Darmawan, N. K. S. (2017). Hukum Perdangan Internasional. Bandung: Refika Aditama.

UNWTO. (2004). Sustainable Tourism in Protected Areas Guide Lines for Planning and Management. Madrid. Spain.: UNWTO.

Widiatedja, I. G. P. (2011). Kebijakan liberalisasi pariwisata: konstruksi konsep, ragam masalah, dan alternatif solusi. Denpasar: Udayana University Press.

\section{Jurnal}

Adipatni, S. A. D. (2018). Perlindungan Hukum terhadap Wisatawan yang Mendapat Perlakuan Diskriminatif. Jurnal Magister Hukum Udayana (Udayana Master Law Journal), 7(1). 122-132. https://doi.org/10.24843/JMHU.2018.v07.i01.p10

Dewi, S. L., \& Sonhaji, B. I. (2017). Penerapan Prinsip Non Diskriminasi Dan Kesetaraan Dalam Pengupahan Bagi Pekerja/Buruh Di Kabupaten Kendal. Diponegoro Law Journal, 6(1), 1-21.

44 Putra, I. B.W., \& Darmawan, N. K. S. loc.cit, h. 45.

45 Ibid, h. 97. 
Dharmawan, N. K. S., Nurmawati, N. M., \& Sarna, K. (2011). The Right to Tourism Dalam Perspektif Hak Asasi Manusia Di Indonesia1. Kertha Patrika, 36 (2), 3-20.

Dharmawan, N. K. S. (2012). Tourism and Environment: Toward Promoting Sustainable Development of Tourism: A Human Rights Perspective. Indonesia. L. Rev. 2 (1). 23 44. http://dx.doi.org/10.15742/ilrev.v2n1.10

Dharmawan, N. K. S. (2014). Keberadaan dan Implikasi Prinsip MFN dan NT dalam Pengaturan Hak Kekayaan Intelektual di Indonesia. Jurnal Magister Hukum Udayana (Udayana Master Law Journal).3(2). 259-274. https://doi.org/10.24843/JMHU.2014.v03.i02.p03

Hartiana, A. (2016). Prinsip-Prinsip Gats (General Agreement on Trade in Services) Terhadap Perdagangan Jasa Pendidikan Tinggi. Jurnal Magister Hukum Udayana $\begin{array}{lllll}\text { (Udayana Master Law Journal). } & \text { 5(4). }\end{array}$ https://doi.org/10.24843/JMHU.2016.v05.i04.p09

Korah, R. S. (2016). Prinsip-prinsip Eksistensi General Agreement on Tariffs and Trade (GATT) Dan World Trade Organization (WTO) Dalam Era Pasar Bebas. Jurnal Hukum UNSRAT. 22(7). 44-52.

Landra, P. T. C. (2018), Hukum Investasi dalam Industrialisasi Kepariwisataan Bali. Jurnal Magister Hukum Udayana (Udayana Master Law Journal). 7(1). 100-121. https://doi.org/10.24843/JMHU.2018.v07.i01.p09

Made, P. I., \& Wayan, S. I. (2015) Model Hubungan Pariwisata, Kinerja Perekonomian Dan Kemiskinan Di Kabupaten Badung, Bali. PIRAMIDA. Denpasar.

Made, P. I., \& Wayan, S. I. (2015). Model Hubungan Pariwisata, Kinerja Perekonomian Dan Kemiskinan Di Kabupaten Badung, Bali. PIRAMIDA, 11(2). 95-100.

Rois, I., Fadliyanti, L., \& Wijimulawiani, B. S. (2018). Dampak Pengembangan Pariwisata Terhadap Pendapatan Asli Daerah (PAD) Di Kabupaten Lombok Tengah, Nusa Tenggara Barat Tahun 2002-2016. Journal of Economics and Business, 3(2), 19-28.

Randang, F. B. (2011). Kesiapan Tenaga Kerja Indonesia Dalam Menghadapi Persaingan Dengan Tenaga Kerja Asing. SERVANDA_Jurnal Ilmiah Hukum, 5(1), 66-73.

Santosa, A. G. D. H., Ranawijaya, I. B. E., Ariana, I. G. P., Salain, N. M. S. P. D., \& Widiatedja, I. P. (2011). Prinsip Non Diskriminasi Perjanjian General Agreement on Trade In Services (GATS) Pada Pengaturan Penanaman Modal Asing Di Bidang Pariwisata Di Indonesia. Kertha Patrika 36 (2). 72-84

Subekti, R. P. (2018). Urgensi Ratifikasi Konvensi International Labor Organization: Perspektif Perlindungan Pekerja Anak Pada Sektor Rumah Tangga. Jurnal Magister Hukum Udayana (Udayana Master Law Journal). 7(1). 24-36. https:// doi.org/10.24843/JMHU.2018.v07.i01.p03 
Simamora, A., Nasution, B., Suhaidi, S., \& Siregar, M. (2014). Liberalisasi Pendidikan dalam Kerangka Gats: Kajian Hukum terhadap Pendirian Perguruan Tinggi Asing di Indonesia. USU Law Journal, 2(1), 67-89.

Putra, P. N. B. R. C., \& Landra, P. T. C. (2017) Pengaturan Hukum Terhadap Advokat Asing Yang Beracara Di Indonesia Ditinjau Dari Undang-Undang No 18 Tahun 2003 Tentang Advokat. Jurnal Magister Hukum Udayana (Udayana Master Law Journal). 6(2). 136-152. https:// doi.org/10.24843/JMHU.2017.v06.i02.p01

Pebrianto, D. Y. (2018). Implikasi Prinsip Most Favoured Nation terhadap Pengaturan Tarif Impor Di Indonesia. Wajah Hukum. 2(1). 29-41.

\section{$\underline{\text { Internet }}$}

Badan Pusat Statistik. Tingkat Pengangguran Terbuka, https://www.bps.go.id/pressrelease/2017/11/06/1377/agustus-2017--tingkatpengangguran-terbuka--tpt--sebesar-5-50-persen.html . accessed 18 Februari 2018

GATS Indonesia Schedule of Specific Commitments, https://docs.wto.org/dol2fe/Pages/FE_Search/FE_S_S009DP.aspx?language $=E \&$ CatalogueIdList $=10332,11366,37274,16557 \&$ CurrentCatalog ueIdIndex $=3 \&$ FullTextHash $=\&$ HasEnglishRecord $=$ True \&HasFrenchRecord $=$ True \&HasSpanishRecord=True, accessed 5 mei 2018

Info Kementrian. Laporan 3 Tahun Pemerintahan Jokowi-JK Sektor Pariwisata. http://www.presidenri.go.id/berita-aktual/laporan-3-tahun-pemerintahanjokowi-jk-sektor-pariwisata.html . accessed 21 Februari 2018

Info Kementrian. Pariwisata Indonesia Semakin Berjaya. http://www.presidenri.go.id/info-kementrian-lembaga/pariwisata-indonesiasemakin-berjaya.html . accessed 18 Februari 2018

\section{Peraturan Perundang-Undang}

Undang-Undang Nomor 7 Tahun 1994 tentang Pengesahan Agreement Establishing of The World Trade Organization

Undang-Undang Nomor 13 Tahun 2003 Tentang Ketenagakerjaan

Undang-Undang Nomor 9 Tahun 2010 Tentang Kepariwisataan

Undang-Undang Nomor 12 Tahun 2011 Tentang Pembentukan Peraturan PerundangUndangan

Peraturan Menteri Ketenagakerjaan Nomor 16 Tahun 2015 Tentang Tata Cara Penggunaan Tenaga Kerja Asing.

Peraturan Menteri Ketenagakerjaan Republik Indonesia Nomor 35 Tahun 2015 Tentang Perubahan Atas Peraturan Menteri Ketenagakerjaan Nomor 16 Tahun 2015 Tentang Tata Cara Penggunaan Tenaga Kerja Asing. 